\title{
Avrupa Birliği Ülkeleri ve Türkiye'nin İnovasyon Performansının Çok Kriterli Karar Verme Yöntemleriyle Kıyaslanması
}

\author{
Burcu Oralhan ${ }^{1}$, Miraç Alper Büyüktürk ${ }^{2}$ \\ ${ }^{1}$ Nuh Naci Yazgan Üniversitesi, İktisadi ve İdari Bilimler Fakültesi, İşletme Bölümü, Kayseri, Türkiye (ORCID: 0000-0001-8905-0140) \\ 2 Nuh Naci Yazgan Üniversitesi, İktisadi ve İdari Bilimler Fakültesi, İşletme Bölümü, Kayseri, Türkiye Türkiye (ORCID: 0000-0001-7878-9505)
}

(İlk Geliş Tarihi 29 Mayıs 2019 ve Kabul Tarihi 4 Temmuz 2019)

(DOI: 10.31590/ejosat.571284)

ATIF/REFERENCE: Oralhan, B. \& Büyüktürk, M. A. (2019). Avrupa Birliği Ülkeleri ve Türkiye'nin İnovasyon Performansının Çok Kriterli Karar Verme Yöntemleriyle Kıyaslanması. Avrupa Bilim ve Teknoloji Dergisi, (16), 471-484.

\begin{abstract}
Özx
Küreselleşen dünyada ülkelerin, şirketlerin veya diğer tüm organizasyonların faaliyetlerinin sürdürülebilir olması ve güçlü bir şekilde ayakta kalabilmeleri için yeniliğe hızlı adapte olması gerekmektedir. Sürdürülebilir ekonomik gelişmelerin sağlanmasında, toplumların refah düzeyinin artırılmasında ve işletmeler için rekabet dinamiğinin geliştirilmesinde inovasyon vazgeçilmez bir kaynaktır. İnovasyon doğru, sistematik ve etkin uygulandığında toplumun, ülkenin veya işletmenin gelişmesi kaçınılmazdır. Bu çalışmada Avrupa Birliği ülkeleri ve Türkiye'nin inovasyon performansının çok kriterli karar verme yöntemleriyle kıyaslanması amaçlanmıştır. Avrupa İnovasyon Endeksi hesaplamasında kullanılan insan kaynakları(IK), araştırma sistemleri (AS), yenilikçi ortam (YO), finansman ve destek (FD), yenilikçiler (Y), bağlantılar (B), entelektüel varlıklar (EV), istihdam etkileri (IE) ve satı̧s etkileri (SE) olmak üzere 10 temel gösterge çok kriterli karar verme metotları ile değerlendirilmiş̧ir. Değerlendirmede Avrupa Birliği'ne üye olan 28 ülke, Türkiye'nin de aralarında bulunduğu 3 aday ülke ve 5 adet komşu ülkenin inovasyon performansları incelenmiştir. 2018 yılı Avrupa İnovasyon Endeksi Puanlama tablosundan temin edilen göstergelerin değerleri, çok kriterli karar verme yöntemlerinden TOPSIS ve MOORA metotlarıyla kıyaslanarak ülkelerin inovasyon performansı sıralaması yapılmıştır. Yöntemlerin sonuçları birbirine yakın olmasına rağmen bazı ülkelerin sıralamalarda değişiklikler gösterdiği tespit edilmiştir. Ülkelerin inovasyon performansları incelendiğinde TOPSIS ve MOORA yöntemine göre ilk üç sırada İsviçre, İsveç ve Danimarka yer almaktadır. Son üç sıralama ise TOPSIS yöntemine göre Ukrayna, Romanya ve Makedonya olarak elde edilirken, MOORA Yöntemine göre ise Romanya, Ukrayna ve Polonya'dır. Sonuçlar incelendiğinde Türkiye TOPSIS Yöntemine göre 31. ve MOORA yöntemine göre ise 33. sırada yer almaktadır. Türkiye'nin inovasyon performansına alt kriter bazlı sıralamalarda bakıldığında ise; ilk on ülke arasında olduğu tek temel kriter 'firma yatırımları' olduğu gözlemlenmiştir.
\end{abstract}

Anahtar Kelimeler: İnovasyon, inovasyon göstergeleri, çok kriterli karar verme, TOPSIS, MOORA, Avrupa Birliği.

\section{Comparison Of European Union And Turkey's Innovation Performance By Using Multi Criteria Decision Making Methods}

\begin{abstract}
In a globalizing world, the activities of countries, companies or all other organizations need to be adoptable to innovation in order to sustainable and to remain strong. Innovation is an indispensable source for achieving sustainable economic developments, increasing the welfare of societies and development competitive dynamics for enterprises. When innovation is used correctly, systematically and effectively, the development of society, country or business is inevitable.
\end{abstract}

\footnotetext{
${ }^{1}$ Sorumlu Yazar: Nuh Naci Yazgan Üniversitesi, İktisadi ve İdari Bilimler Fakültesi, İşletme Bölümü, Kayseri, Türkiye, ORCID: 0000-0001-89050140, boralhan@,nny.edu.tr
} 
In this study, it is aimed to European Union countries' and Turkey's innovation performances are compared to by using multi-criteria decision-making methods. The significant indicators such as Human resources (IK), research systems (AS), innovative environment (YO), financing and support (FD), innovators (Y), links (B), intellectual assets (EV), employment impacts (IE) and sales impacts (SE) which are based on European Innovation Index has been used. 28 member countries of the European Union, 6 neighbour countries and 4 of the candidate countries' including Turkey innovation indicators and their sub-criterias performance is calculated and ranked by using multi-criteria decision-making methods. The performance scores of the indicators obtained from the 2018 European Innovation Index. The countries' innovation performances were ranked by using datas which is obtained from TOPSIS, VIKOR and MOORA multi-criteria decision making methods. Although the results of the methods were close to each other, it was determined that some countries differ in the rankings. When the results are examined, Turkey is seen in 31th place according to results of TOPSIS and VIKOR. Also, seen in 33th place according to MOORA Method. According to TOPSIS and VIKOR method, the first three countries are Switzerland, Sweden and Denmark. Ukraine, Romania and Macedonia are last three places. According to MOORA method, Sweden, Switzerland and Denmark are the top three, while, Romania, Ukraine and Poland are the last three. When Turkey's subcriteria ranking based on innovation performance is viewed; it is seen that the only basic criterion among the top ten countries is 'firm investments'.

Keywords: Innovation, Innovation Indicators, Multi Criteria Decision Making, TOPSIS, MOORA, European Union.

\section{Giriş}

Günümüzde makro çapta ülkelerin ve ekonomilerin, mikro çapta işletmelerin ayakta kalmasını sağlayan en önemli faktörlerden biri 'İnovasyon' kavramıdır. Yakın tarihte kısa dönemlerde değişim ve gelişim gösteren teknolojiler söz konusu iken, hızla yaygınlaşan teknoloji üretim, satış, pazarlama, yönetim ve istihdam politikalarına entegre edilerek son derece yenilikçi ürün ve hizmetler ortaya çıkarmaktadır. Bunun sonucunda, bu ürün ve hizmetlerin insanların hayatlarını kolaylaştırdığı, ufkunu genişlettiğgi, ülkelere ve/veya şirketlere fayda maksimizasyonu sağladığı görülmektedir. Sürdürülebilirlik, yüksek istihdamı oranı, düşük cari açık oranı ve ihraç fazlası gibi bir ülkenin en önemli emellerinin gerçekleştirilmesinde yenilikçilik politikaların benimsenmesi gerekmektedir. Yeniliklere ayak uyduramayan sistemlerin, organizasyonların entropiye daha kısa sürede maruz kalması yadsınamaz bir gerçektir. Kısacası inovasyonun yine mikro perspektifte işletmeler ve organizasyonların, makro çapta ülkelerin refah seviyesini yükseltmek, küresel rekabette ayakta kalmalarını sağlayan bir faktör olduğunu, önemle vurgulamak gerekir. İnovasyon kavramı yeni ve geliştirilmiş olan ürün ve süreçlerin yeni organizasyonel yapılar ile var olan teknolojinin yeni alanlarda kullanılmasının sağlanması ve yeni pazarların keşfedilmesi olarak tanımlandığı görülmektedir (Nafgizer, 2006, s. 393). İnovasyon, OECD tarafından hazırlanmış olan Oslo El Kitabı incelendiğinde; işletme içerisinde, işletme organizasyonlarında ya da dış ilişkiler içerisinde gerçekleştirilen yenilik, ya da önemli derecede iyileştirilmiş olan bir ürün/hizmet ya da süreç, yeni bir pazarlama yöntemi veya örgütsel yöntemin gerçekleştirilmesi olarak adlandırılmaktadır (Oslo Kılavuzu, 2006, s. 50). İnovasyon; değişmek, yenilenmek ve daha yaratıcı ve iyi ürünler, hizmetler ortaya çıkarmak, daha önce denenmemişi denemek anlamına da gelmektedir. Ayrıca, geliştirilmiş veya yeni ürünler, stratejiler, süreçler veya hizmet üreten fikirler geliştirerek, uygulayarak ve üreterek sosyal ve ekonomik değerin bilgiden elde edildiği bir süreç olarak tanımlanabilir.

İnovasyon, günümüz rekabet ortamında hayati bir öneme sahiptir. İşletmeler rekabet avantaj1 elde edebilmek için hem rakiplerinden daha hızlı bir biçimde yeni teknolojiler geliştirmek, hem de inovasyon süreçlerini sürdürülebilir hale getirmek zorundadırlar. Bir ülke kendi inovatif çalışmalarını yürütemezse, bu durum beraberinde o ülkenin birçok ürün için yurtdışına bağımlılığını gerektirecektir ve cari bütçe açığında artış olmasına sebep olmaktadır (Kaynak, Altuntaş ve Dereli, 2017, ss. 32-33). Bu faktörün etkilerini ölçmek için dünya üzerinde belirli kurum ve kuruluşlar çeşitli endeksler hesaplamaktadır. Hesaplanan endekslerin sonucunda ortaya çıkan veriler ışığında ülkelerin inovasyon performansları kıyaslanabilmektedir. Öte yandan, aynı şekilde mikro çapta belirli araştırma şirketleri veya akademisyenler tarafından sektörel ve firmasal bazda bazı endeksler oluşturulmaktadır. KOBİlerin bulundukları pazarda kendinden büyük firmalarla rekabet etmesi için sürekli yeni ürünler ve hizmetler ortaya koyması gerektiği göz önünde bulundurulursa, inovasyonun önemi daha iyi kavranacaktır (Örücü vd., 2011, ss. 58-59). Benzer durum ülkeler içinde geçerli olduğunda, ülkelerin diğer ülkelerle aynı pazarda rekabet gücüne sahip olması için yeniliğin gücüne ihtiyaç duyulmaktadır. Yeni ürün, hizmet ve teknolojiler üreten işletmeler gibi ülkelerin de ekonomik büyümesi ve kalkınma hızındaki ivmelenme giderek artacaktır. İnovasyonun, ülke ekonomisine katkısı, ülke sınırları içerisinde üretilen bilginin ticarileştirilmesi neticesinde katma değer sağlamaktır (Işık ve Keskin, 2013, ss. 42-43). Bunların yanında yaşam kalitesinin artması, ekonomik büyümenin sürdürülebilir hale getirilmesi, verimliliğin ve istihdamın artması gibi katkıları da bulunmaktadır (Işık ve Keskin, 2013, s. 44). Ayrıca, ülke ve topluma ait kaynakların ürüne dönüştürülmesi yoluyla ekonomik değer haline getirilmesi de yine inovasyonun sonuçlarından biridir. Bununla beraber, inovasyon yoluyla işletmelerin verimliliği ve karlılığı arttığından, ülke ekonomisi küresel düzeyde rekabet avantajı elde etmektedir. Bunun sebebi ise işletmelerin bu yenilikleri çevresine ve böylece tüm ekonomiye bir çeşit dinamizm kazandırmasıdır (Mercan ve Gömleksiz, 2013, s.4).

İnovasyonun ve türlerinin tanımına yönelik çok sayıda kaynak bulunmaktadır. Literatür incelendiğinde inovasyonun derecelerine, alanlarına ve özelliklerine göre birçok sınıflandırmaya tabi tutulmuştur. İnovasyon ile ilgili olarak meydana gelen değişim ve farklılığa göre inovasyon radikal ve artırımsal inovasyon olarak ikiye ayrılmaktadır. (Ettlie vd., 1984, s. 682). Tablo 1'de inovasyon türleri ve tanımları yer almaktadır. Ayrıca bu tabloda inovasyonun alanına ve derecesine göre sınıflandırma yapılmıştır. 
European Journal of Science and Technology

Tablo 1. Inovasyon Türleri ve Tanımlarl

\begin{tabular}{|c|c|c|}
\hline & İnovasyon Türleri & Kisa Tanımı \\
\hline \multirow{4}{*}{$\begin{array}{l}\text { Alanına Göre } \\
\text { İnovasyon }\end{array}$} & Ürün İnovasyonu & Yeni bir ürünün çıkarılması veya mevcut bir ürünün çok büyük ölçüde değiştirilmesidir. \\
\hline & Süreç İnovasyonu & $\begin{array}{l}\text { İşletmenin birim maliyetini azaltacak şekilde üretim veya teslimat süreçlerinde yapılan } \\
\text { inovasyondur. }\end{array}$ \\
\hline & Organizasyonel İnovasyon & $\begin{array}{l}\text { Yönetim Maliyetlerini azaltma, daha hızlı kararlar alma, organizasyon esneklik sağlama } \\
\text { amacıyla yapılan inovasyon türüdür. }\end{array}$ \\
\hline & Pazarlama İnovasyonu & Sektör için yepyeni bir ürün, süreç veya iş yapma şeklinin ortaya çıkarılmasıdır. \\
\hline $\begin{array}{l}\text { Derecesine Göre } \\
\text { İnovasyon }\end{array}$ & Artımsal İnovasyon & Var olan üzerine yapılan geliştirmeler anlamına gelen inovasyondur. \\
\hline
\end{tabular}

Kaynak: (Adı̈̈zel, 2012, s. 25)

Tablo 1'de bahsedilen inovasyon türleri tanım ve içerik olarak mikro çapta işletmeler ve organizasyonlar için yapılmış iken, aslında makro çapta ele alındığında ülkeler açısında değerlendirilebilecek türlerdir. İnovasyon, yeni fikirlerin ürünlere ve süreçlere ya da toplumsal ve firma faaliyetlerinin katma değer oluşturacak diğer yönlerine uygulanması olarak da tanımlanabilmektedir. Araştırmanın, kıyaslama tarafını oluşturan $\mathrm{AB}$ açısından bakıldığı zaman da, inovasyonun önemi Avrupa Birliği ülkelerinin yakın gelecekte lider pozisyonda olmak istemesi ve finansal krizlerden kaçınmak talebinden daha fazla önem arz etmektedir. Bu yüzden Avrupa Birliği'ne üye olan ülkelerin kendi arasında yaptığı inovasyon performansı karşılaştırmaları önemli bir araştırma konusudur.

Ulusal ve uluslararası literatürde inovasyona yönelik birçok çalışma yapıldığı görülmektedir. Konuyla ilgili literatürdeki çalışmalar incelendiğinde, genellikle Avrupa Birliği ile diğer ülkelerin ilişkisi, anlaşmalar, prosedürler ve yapısal reformlara dikkat çekilmiştir. Ayrıca Avrupa Birliği’ne aday ülke tarafindan iyileştirilmesi gereken faaliyete odaklanılmıştır. Literatürde inovasyonu ölçen ve ülkelerin inovasyon performanslarını ortaya koyan birçok gösterge bulunmaktadır. Yazarlar ve kurumlar tarafından inovasyon farklı şekillerde sınıflandırılmasına ve farklı göstergelerle değerlendirilmesine rağmen, en yaygın olarak kullanılan OECDEurostat (2006) tarafından hazırlanan sınıflandırmadır (Oslo Kılavuzu, 2006). Kılavuza göre ürün, süreç, pazarlama yöntemi veya organizasyonel yöntemlere yönelik inovasyonlar incelenmelidir.

Lööf, Heshmati, Asplund ve Naas (2001, s. 119) inovasyon ve verimlilik arasındaki ilişkiyi, Toplumsal İnovasyon Anketi ve üç ülke için (Finlandiya, Norveç ve İsveç) yapılan CDM modelindeki verileri kullanarak incelemiştir. Jungmittag (2004) inovasyonun, teknolojik özelleştirmenin ve teknoloji difuzyonunun, 1969'tan 1998'e kadar olan süreç AB'nin ekonomik büyümesine ve iyileştirilmesine olan etkilerini, panel veri modelini kullanarak değerlendirmiştir. Oprean ve Tanasescu (2007, s. 35) Romanya'nın inovasyon potansiyelini 2007 'deki aday ülke olan Türkiye, 25 AB üyesi olan, olmayan ve aday olmayan ülkelerle Avrupa İnovasyon Skorkartı'ndan elde edilen verileri kullanarak, kıyaslama yapmıştır. Tokumasu ve Watanabe (2008, s. 48), 15 AB üyesi ülkenin inovasyon kapasitesi, kabiliyetini, onların inovasyon yeterliliğini, inovasyon jenerasyonu ve enstitü yapısı adı verilen üç değişkeni kullanarak analiz etmiştir. Bunu yaparken, çoklu regresyon analizi, küme analizi ve temel bileşenler analizi uygulamışlardır. AutantBernard vd. (2010), 22 AB ülkesi ve farklı endüstriler için inovasyon adaptosyonunun büyüklüğünü incelemişlerdir. Ayrıca, inovasyon adaptasyonu için Toplumsal İnovasyon Anketi'nde yer alan yeni kriterleri tavsiye etmişlerdir. Fernandez-Ribas (2010, s. 55) Amerika ve Avrupa'yı ABD'deki bazı eyaletlerde, İngiltere'de ve İspanya'daki üretim firmalarının inovasyon performanslarındaki faktörleri çoklu varyasyon modelini kullanarak, kıyaslamıştır. Suurna ve Kattel (2010, s. 90), AB'nin Orta ve Doğu Avrupa'nın inovasyon politikalarını incelemişlerdir. Paas ve Poltimae (2010) Baltık ülkelerinin ulusal inovasyon performanslarını, AB'nin içeriğindeki 'Avrupa İnovasyon Skorkartı'nda yer alan kriterlere göre faktör analizi kullanarak, kıyaslamışlardır. Pan, Hung ve Lu (2010) 33 Asya Ülkesi ve Avrupa Ülkelerinin ulusal inovasyon sistemlerinin performanslarını 'Veri Geliştirme Analizi’ yaklaşımıyla ölçmüşlerdir.

2009 yılında Ersöz'ün yapmış olduğu Avrupa inovasyon göstergeleri 1şı̆̆ında Türkiye'nin konumu açıklanmıştır. Çalışmada özellikle Türkiye'nin gelişmiş ülkeler düzeyine çıkabilmesi için ihtiyaçlarının belirlenerek, bu ihtiyaçlara uygun stratejilerin ortaya konması ve inovasyon göstergelerine göre öncelikli olarak hangi alanlara odaklanılması gerektiğini çok değişkenli istatistik teknikleri uygulanarak ortaya konulmuştur. Şahinli ve Kılınç (2013, s. 332) tarafindan bilgi yoğun sektörlerdeki istihdam, Toplam Faktör Verimliliği (TFV), Ar-Ge harcamaları, patent başvuru ve tescil sayıları, girişimci, araştırmacı ve teknisyen sayıları, ileri teknoloji ihracatı, royalti ve lisans ücretleri, endüstri katma değeri, inovasyon kapasitesi ile Bilgi ve İletişim Teknolojileri (BİT)'nin ihracatı gibi göstergeler 1şığında Avrupa Birliği ülkeleri ve Türkiye arasında bir kıyaslama yapmıştır. Araştırmada, inovasyon etkileyen en önemli göstergeler olarak; Ar-Ge harcamaları, ileri teknoloji ihracatı ile bilgi ve teknolojideki insan kaynaklarının işgücü içerisindeki payı dikkat çekmiş ve gelişmiş AB ülkelerinde GSYH içinde Ar-Ge paylarının yüksekliğine değinilmiştir. Avrupa Birliği’ne yeni katılan ülkeler ve Türkiye'de ise bu oranlar, AB-27 ortalamasının altında seyretmekte olduğu ve gelişmişlik ile Ar-Ge harcamaları arasında doğrusal bir ilişkiden söz edilebileceği belirlenmiştir. Türkiye'nin Avrupa Birliği’ne üye veya aday ülkelerine kıyasla Ar-Ge harcamalarında, ileri teknoloji ihracında ve işgücü içerisindeki bilgi ve teknolojideki insan kaynaklarının payı bakımından belirgin bir şekilde geride kaldığı ifade edilmiştir. AB ülkeleri ve Türkiye arasında inovasyon göstergeleri bakımından kıyaslamasına yönelik 2012 y1lında hazırlanan bir çalışmada Kümeleme Analizi'nden faydalanılmıştır. Hiyerarşik kümeleme yöntemlerinden biri olan WARD yöntemini kullanan araştırmacılar, bu sayede inovasyon göstergeleri bakımından benzer performansa sahip ülkeleri ortaya koymuşlardır. Araştırmada kullanılan göstergeler ise beş ana başlık altında toplanmıştır bunlar; Ar-Ge Göstergeleri, Eğitim Göstergeleri, Patent Göstergeleri, Endüstriyel Tasarım ve Ticari Marka Göstergeleri ve son olarak Diğer Göstergeler'dir. Bunların alt başlıkları ile toplamda 13 gösterge, WARD yöntemi ile kümeleme analizine tabi tutulmuş; elde edilen bulgular neticesinde $27 \mathrm{AB}$ ülkesi arasında Türkiye'nin inovasyondaki konumu belirlenmiştir. Göstergelere uygulanan metotlar sonucunda, ülkeler dört gruba 
ayrılmış ve bu gruplar, inovasyonda lider ülkeler, inovasyonda takipçi ülkeler, sınırlı derecede inovatif ülkeler ve inovatif olmayan ülkeler olarak nitelendirilmiştir. Bu araştırma sonucunda, Türkiye 3. grupta yer aldığını görülmüştür. Bir önceki araştırmada kullanılan kriterlerden Ar-Ge harcamalarının arttırılması, uluslararası patent alımının arttırılması, ileri teknoloji üretimi ve ihracatındaki önemi bu çalışmada da görülmektedir (Atik ve Özbek, 2012, s. 194).

Türkiye'nin inovasyon performansının belirlenmeye çalışıldığı bir araştırmada, kriterler dört farklı kaynaktan alınarak, nitel bir analiz yapmıştır. Bu kaynaklar 'Avurpa Birliği İnovasyon Birliği Skor Tahtası 2011 Raporu', 'Insead Raporunda Türkiye'nin Konumu', 'The Economist Intelligence Unit (EIU) Dünyanın En Yenilikçi Ülkelerinin Sıralaması Çalışması' ve 'Türkiye'nin Konumu', 'Dünya Bilgi Ekonomisi Endeksi ve Türkiye'nin Konumu'dur. Bu raporların sonucunda Türkiye inovasyon alanında en iyi performans ortaya koyan ülkelerden biri olmadığ görülmüştür. Bu araştırma sonucunda Türkiye, Ar-Ge ve inovasyona verilen teşvikler, ulusal inovasyon sistemi içinde gereksinim duyulan kurumların varlığı ve bilimsel yayınlar gibi kıstaslarda göreli iyi performans sergilemiştir. Fakat inovasyon yapabilmek için yetkin insan kaynağı ve bu kıstasa bağlı olarak daha bağlayıcı bir kıstas olarak dikkate alınabilecek genel eğitim sistemi ve fikri mülkiyet hakları alanları, Türkiye'nin geliştirmesi gereken başlıklar arasında gösterilmektedir (Karaata, 2012, s. 35). Çok değişkenli istatistiksel yöntemlerle Türkiye ve $A B$ ülkelerinin ar-ge ve inovasyon göstergeleri yönünden sınıflandırılmasına yönelik yapılan farklı bir çalışmada inovasyon düzeylerini Ar-Ge, patent sayıları ve eğitim düzeylerini de içine alan 'Temel İnovasyon Göstergeleri'ile açıklamışlardır. Bu nedenle Türkiye'nin 2012 Yılı Temel İnovasyon Gösterge değerlerine göre Avrupa Birliği (AB) ülkeleri arasındaki konumu tartışılmıştır. Bu doğrultuda, Türkiye ve Avrupa Birliği üyesi ülkeler 2012 dönemi için benzerlikleri ve farklılıkları açısından gruplandırılmıştır. 29 ülke için yapılan kümeleme analizinde Ward tekniği kullanılmış ve Türkiye'nin bu ülkeler arasında seçilen değişkenlere göre hangi kümede yer alacağı tartışılmıştır. Ayrıca, değiş̧kenlerin kümeleri birbirinden ayırma düzeyi için MANOVA LSD düzeltmeli istatistikleri kullanılmış ve belirlenen küme sayısının tutarlılı̆̆ını test etmek için Discriminant Analizi yapılmıştır (Uzgören ve Elevli, 2013, s. 78).

Türkiye'nin Avrupa Birliği sürecinde ekonomik açıdan durumunun tespit edilmesi ve $\mathrm{AB}$ üye, aday ülkeleri ile Türkiye'nin ekonomik performanslarını karşılaştırılmasına yönelik hazırlanan bir çalışmada Çok Kriterli Karar Verme yöntemleri uygulanmıştır. $\mathrm{Bu}$ çerçevede, araştırmada ikili karşılaştırmalar yaparak organizasyonların kriterler bazında skorlarını ortaya koyma temeline dayanan ELECTRE yöntemini, önceden belirlenmiş tercih fonksiyonlarından yararlanarak ikili karşılaştırma yapan PROMETHEE yöntemini ve organizasyonların performanslarını pozitif ideal çözüme yakınlığına göre sıralayan TOPSIS yöntemi kullanılmışır (Urfalığlu ve Genç, 2013, s. 360). Farklı bir çalışmada beş ayrı inovasyon göstergesi belirlenerek kümeleme analizi ile değerlendirme yapmıştır. Hiyerarşik kümeleme yöntemlerinden biri olan WARD yöntemini kullanılan araştırma sonucunda, Türkiye'nin inovasyonda 3. grupta yer aldığı görülmüştür. Ülkelerin inovasyon performansının ölçülmesine yönelik yapılan farklı bir çalışmada Çok Kriterli Karar Verme Yöntemlerinden Analitik Hiyerarşi Süreci ve TOPSIS'i kullanarak inovasyon endeksleri hesaplanmıştır. Oslo Kılavuzu ve Avrupa İnovasyon Skor tahtasındaki 2013 ve 2014 yılı verileri esas alınarak hazırlanan çalışmada, kriterler; gayri safi yurt içi hâsıla, gayri safi yurtiçi hâsıla içindeki Ar-Ge harcamaları ve kişi başına düşen patent sayıları olarak belirlenmiştir (İnel ve Türker, 2016, s. 148). Avrupa Birliği ülkelerinin inovasyon performansları hesaplanmıştır. Kaynak, Altuntaş ve Dereli (2017, s. 38), Avrupa Birliği'ne aday ülkeler, İzlanda, Makedonya, Sırbistan ve Türkiye'nin inovasyon performanslarının kıyaslamasını, 'Bilgi Temelli Yaklaşım'dan 16 değişken, 'Global Rekabetçilik Endeksi”'nden 7 değişken, 'İnovasyon Birliği Skor Tahtası'ndan 8 değişken, 'Global İnovasyon Endeksi”'nden ise 8 değişken kullanarak ele alınmışlardır. Araştırmalarında ‘Entropi Temelli Topsis Metodu' uygulanmış olup, Avrupa Birliği’ne aday dört ülke arasında bir sıralama yapmışlardır. Ünlükaplan (2009) ise araştırmasında Kanonik Korelasyon Analizini kullanarak, $\mathrm{AB}$ ülkelerinde rekabetçilik, inovasyon ve ekonomik gelişme arasında ilişkiyi incelemiştir.

$\mathrm{Bu}$ çalışmada Avrupa Birliği ülkeleri, aday ülkeler ve Türkiye'nin inovasyon performansının çok kriterli karar verme yöntemleriyle kıyaslanması amaçlanmıştır. Bu amaçla 2018 yılı Avrupa İnovasyon Endeksi değerleri temel alınarak TOPSIS ve MOORA çok kriterli karar verme yöntemleri ile birlikte bahsi geçen ülkelerin inovasyon performansları kıyaslanmıştır. TOPSIS ve MOORA yönteminden elde edilen skorlara göre en iyi performansa sahip ilk üç ve son üç sıradaki ülkelerin belirlenmesi ve Türkiye'nin bu ülkeler arasındaki yerinin ve iyileştirmesi gereken kriterlerin belirlenmesi hedeflenmiştir.

\section{Materyal ve Metot}

\subsection{Araştırmanın Amacı}

Bu çalışmada Avrupa Birliği’ne üye olan 28 ülke, Türkiye'nin de aralarında bulunduğu 3 aday ülke ve 5 adet komşu ülke ve Avrupa Birliği ortalamasını içerek şekilde ülkelerin inovasyon performansının çok kriterli karar verme yöntemleriyle kıyaslanması amaçlanmıştır. Bu amaçla 2018 yılı Avrupa İnovasyon Endeksi değerleri temel alınarak TOPSIS ve MOORA çok kriterli karar verme yöntemleri ile ülkelerin inovasyon performansları kıyaslanmışıtr. Avrupa İnovasyon Endeksi hesaplamasında kullanılan 10 temel gösterge ile inovasyon performansları analiz edilmiştir. TOPSIS ve MOORA yönteminden elde edilen skorlara göre en iyi performansa sahip ilk üç ve son üç sıradaki ülkelerin belirlenmesi hedeflenmiştir. Türkiye'nin bu ülkeler arasındaki yerinin belirlenmesi ve değerlendirmesi yapılmıştır. Bu hesaplamalar yapılırken inovasyon ölçüm kriterlerinin temeli olan Oslo Kılavuzu ışı̆̆ında hazırlamış olduğu, Avrupa İnovasyon Endeksi’nin, 2018 yılındaki kitapçı̆̆ındaki değişsenlerin tamamı kullanılarak hesaplamalar yapılmıştır.

\subsection{Araştırmanın Sınırlılıkları}

Araştırmada ülkelerin inovasyon performanslarının değerlendirilmesinde Avrupa İnovasyon Endeksi’nde yer alan 10 temel gösterge eşit ağırlıklı olarak kabul edilmiş, Avrupa Birliği üyesi 28 ülke, Türkiye, Sırbistan ve Makedonya'nın aralarında olduğu aday ülkeler ve İzlanda, İsviçre, Ukrayna, Norveç ve İsrail gibi topluluğa komşu toplamda 36 ülke ve Avrupa Birliği Ortalaması 
değerlendirilmiştir. Veriler 2018 yılı Avrupa İnovasyon Endeksi değerleri kullanılarak çok kriterli karar verme yöntemlerinden TOPSIS ve MOORA metotları kullanılarak analiz edilmiştir.

\subsection{Araştırmanın Yöntemi ve Modeli}

Çalışmada, Avrupa İnovasyon Birliği’nin her yıl çıkardığı 'Innovation Scoreboard' (İnovasyon Skortahtası) adı verilen kılavuzdaki verilerin ışığında hazırlanmıştır. Bu kitapçığın araştırmadaki yol haritası olarak kullanılmasının sebebi, 2010 yılından itibaren her y1l düzenli olarak üye ülkelerden, komşu ve aday ülkelerden toplanan nicel verilerle ülkelerin inovasyon performanslarının kıyaslanması sonucu oluşturulan net istatistiksel verilerin mevcut olmasıdır. Yapılan bu çalışmada TOPSIS ve MOORA skorlarının hesaplanmasında kriter olarak kullanılan on temel kriter yer almaktadır. Bunlar; insan kaynakları(IK), araştırma sistemleri (AS), yenilikçi ortam (YO), finansman ve destek (FD), yenilikçiler (Y), bağlantılar (B), entelektüel varlıklar (EV), istihdam etkileri (IE) ve satış etkileri (SE) olarak adlandırılmaktadır.

\subsubsection{TOPSIS}

Karar verme yöntemlerinden en çok kullanılanlarından biri olan TOPSIS, mevcut alternatifler arasından en iyisini ve optimumun seçilmesine yardımcı olan bir metottur. TOPSIS 1981 yılında Hwang ve Yoon tarafinda geliştirilmiş olup, çok kriterli karar verme yöntemlerinden birisidir. TOPSIS kelimesi, Technique for Order Preference by Similarity to Ideal Solution kelimelerinin baş harflerinden oluşmaktadır (Özdemir, 2015, s. 134). Alternatif çözüm noktasının pozitif-ideal çözüme en yakın ve negatif ideal çözüme en uzak mesafede olacağı varsayımına göre oluşturulmuştur. TOPSIS yöntemi nitel bir çevrim yapılmaksızın, direk veriler üzerinde uygulanabilmektedir (Eleren ve Karagül, 2008, s. 110). TOPSIS, karar vericilerin çözümlemesi gereken problemleri organize etmesine, alternatiflerin analiz edilmesine, sıralanmasına ve kıyaslanmasına yardım etmektedir. Böylece en uygun alternatif seçilmiş olmaktadır. Metodun aşamaları aşağıdaki gibi sıralanmıştır.

\section{Adım: Karar Matrisinin Oluşturulmasının Sağlanması}

Öncelikle satırlar arasındaki üstünlüklerin sıralanmak istenilen alternatiflerin, sütunlarda ise karar vermede esas alınan değerlendirme kriterlerinin yer aldığı karar matrisi oluşturulmaktadır. m alternatif ve $n$ değerlendirme kriterinden oluşturulmuş olan başlangıç matrisi aşağıda gösterilmektedir.

$$
A_{\mathrm{I} J}=\left[\begin{array}{cccc}
a_{11} & a_{12} & \cdots & a_{1 p} \\
a_{21} & a_{22} & \cdots & a_{2 p} \\
\cdot & & & \cdot \\
\cdot & & \cdot \\
\cdot & & \cdot \\
a_{m 1} & a_{m 2} & a_{m p}
\end{array}\right] \quad \text { Karar Kriterleri }
$$

\section{Adlm: Standart Karar Matrisinin (R) Oluşturulması}

Karar matrisi içerisinde yer alan başlangıç değerleri aşağıdaki formül kullanılarak standart karar matrisinin oluşturulması sağlanmaktadır. Karar matrisi oluşturulduktan sonra her bir $\mathrm{a}_{\mathrm{ij}}$ değerlerinin $\left(\mathrm{a}_{11}, \mathrm{a}_{21}, \mathrm{a}_{31} \ldots \mathrm{a}_{\mathrm{m} 1}\right)$ kareleri alınarak bu değerlerin toplamından oluşan sütun toplamları elde edilir ve her bir $\mathrm{a}_{\mathrm{ij}}$ değeri ait olduğu sütun toplamının kareköküne bölünür.

$$
n_{i j}=\frac{a_{i j}}{\sqrt{\sum_{i=1}^{m} a_{i j}^{2}}}(\mathrm{i}=1, \ldots, \mathrm{m} \text { ve } \mathrm{j}=1, \ldots, \mathrm{p})
$$

Karar matrisi içerisindeki tüm başlangıç değerlerinin normalize edilmesi sağlanılarak $\mathrm{R}$ ile ifade edilmiş olan standart karar matrisinin oluşturulması sağlanmaktadır.

$$
\mathrm{N}=\left[\begin{array}{cccc}
n_{11} & n_{12} & \ldots & n_{1 p} \\
n_{21} & n_{22} & \cdots & n_{2 p} \\
\vdots & \vdots & \ddots & \vdots \\
\vdots & \vdots & \ddots & \vdots \\
\vdots & \vdots & \ddots & \vdots \\
n_{m 1} & n_{m 2} & \ldots & n_{m p}
\end{array}\right]
$$

\section{Adım: Ağırlıklı Standart Karar Matrisinin (V) Oluşturulması}

Bu aşamada ilk olarak değerlendirme kriterlerinin ağırlıklı olarak belirlenmesi $\left(\mathrm{w}_{\mathrm{i}}\right)$ sağlanmalıdır. Burada dikkat edilmesi gereken husus $w_{\mathrm{i}}$ değer toplamlarının 1'e eşit olmasıdır. Yani $\sum_{\mathrm{i}=1}^{\mathrm{n}} w_{i}=1$ olacaktır.

$$
\mathrm{V}=\left[\begin{array}{cccc}
w_{1} n_{11} & w_{2} n_{12} & \cdots & w_{n} n_{1 p} \\
w_{1} n_{21} & w_{2} n_{22} & \ldots & w_{n} n_{2 p} \\
\cdot & & & \cdot \\
\cdot & & & \cdot \\
\cdot & & & \cdot \\
w_{1} n_{m 1} & w_{2} n_{m 2} & \ldots & w_{n} n_{m p}
\end{array}\right] i_{j}=\left[\begin{array}{cccc}
v_{11} & v_{12} & \ldots & v_{1 p} \\
v_{21} & v_{22} & \ldots & v_{2 p} \\
\cdot & & & \cdot \\
\cdot & & & \cdot \\
\cdot & & & \cdot \\
v_{m 1} & v_{m 2} & \ldots & v_{m p}
\end{array}\right]
$$


Sonrasında R matrisi içerisinde bulunan her bir değer, bağlı olduğu kriterin $w_{i}$ değeri ile çarpılması sağlanılarak Ağırlıklı Standart Karar Matrisi (V) oluşturulması sağlanmaktadır.

\section{Adım: İdeal ( $\left.A^{*}\right)$ ve Negatif İdeal (A-) Çözümlerin Oluşturulması}

TOPSIS Yöntemi içerisinde yapılan her bir değerlendirmenin monoton artan ya da azalan bir eğilim gösterdiği varsayılmaktadır. $\mathrm{Bu}$ nedenle $\mathrm{V}$ matrisinin her bir sütununda yer alan maksimum değer ideal $\left(\mathrm{A}^{*}\right)$ çözümü, minimum değer ise Negatif İdeal (A-) çözümü ifade edilmektedir.

$$
\mathrm{A}^{*}=\left\{\left(\max \mathrm{v}_{\mathrm{ij}} \mid \mathrm{j} \in \mathrm{J}\right),\left(\min \mathrm{v}_{\mathrm{ij}} \mid \mathrm{j} \in \mathrm{JJ}^{\prime}\right\}\right.
$$

Bu eşitlikten elde edilen $A^{*}=\left\{v_{1}, v_{2}, \ldots \ldots v_{n}\right\}$ şeklinde gösterilebilmektedir.

$$
\mathrm{A}^{-}=\left\{\left(\min \mathrm{v}_{\mathrm{ij}} \mathrm{j} \mathrm{j} \in \mathrm{J}\right),\left(\max \mathrm{v}_{\mathrm{ij}} \mathrm{j} \mathrm{j}_{\mathrm{j}} \mathrm{J}^{\prime}\right\}\right.
$$

Bu eşitlikten elde edilen $A^{-}=\left\{v_{1}, v_{2}, \ldots . . v_{n}\right\}$ şeklinde gösterilebilmektedir.

\section{Adım: Ayrım Ölçütlerinin Hesaplanması}

Her bir karar noktasının kriter değerinin elde edilebilmesi için ideal ve negatif ideal çözüm noktalarına olan uzaklığının hesaplanabilmesi için Euclidian Uzaklık Yaklaşımı'ndan faydalanılmaktadır.

$$
\sqrt{\sum_{k=1}^{p}\left(x_{i k}-x_{j k}\right)^{2}}
$$

Formülünden faydalanılmaktadır. Burada $x_{i k}: i$. Gözlemin $k$. değişken değeri, $x_{j k}: j$. Gözlemin $k$. değişken değeri, p: değişken sayısını göstermektedir. Burada her bir alternatifin ideal çözümden uzaklığı ideal ayrım $\left(S_{i}^{*}\right)$ ve negatif ideal çözümden uzaklığı negatif ideal ayrım $\left(S_{i}^{*}\right)$ ölçütleri aşağıda görülen formüllerle hesaplanmaktadır.

İdeal uzaklık:

$$
S_{i}^{*}=\sqrt{\sum_{j=1}^{n}\left(v_{i j}-v_{j}^{*}\right)^{2}}
$$

Negatif ideal uzaklık:

$$
S_{i}^{-}=\sqrt{\sum_{j=1}^{n}\left(v_{i j}-v_{j}^{-}\right)^{2}}
$$

\section{Adım: İdeal Çözüme Göreli Yakınlı̆̆ın Hesaplanması}

İdeal ve negatif ideal ayrım ölçütlerinin kullanılması sonucunda her bir alternatifin ideal çözüme göreli yakınlığı $\left(C_{i}^{*}\right)$ hesaplanmaktadır. Her bir alternatif için hesaplanan negatif ideal ayrım ölçütünün toplam ayrım ölçütü ile içerisindeki payı ile ilgili olan alternatifin $C_{i}^{*}$ değerini göstermektedir.

$C_{i}^{*}$ değeri $0 \leq C_{i}^{*} \leq 1$ Aralığında olarak alternatiflerin $C_{i}^{*}$ değerine göre sıralanmaktadır. $C_{i}^{*}=1$ ilgili karar noktasının ideal çözüme mutlak çözüm yakınlığını gösterirken, $C_{i}^{*}=0$ ise ilgili karar noktasının negatif ideal çözüme mutlak yakınlığını gösterir.

$$
C_{i}^{*}=\frac{S_{i}^{-}}{S_{i}^{-}+S_{i}^{*}}
$$

\subsubsection{MOORA}

2006 yılında Willem Karel M. Brauers ve Edmudas Kazimieras Zavadskas tarafindan yapılan çalışmada tanıtılmıştır. Willem Karel M. Braeurs ve Edmundas Kazimieras Zavadskas tarafindan yapılan 'The MOORA Method And Its Application To Privatization In A Transition Economy' isimli makale çalışması olup MOORA Yöntemi ilk olarak bu çalışmada önerilmiştir. Önerilen bu yeni yöntem, oranların uygulandığı amaçlar için alternatiflerin cevaplarının matrislerini ifade eder. Çok amaçlı optimizasyon için oluşturulmuş diğer yöntem ise karşılaştırma için kullanılan, yani referans noktası yöntemidir (Yıldırım ve Önder, 2015).

Bu çalışmada MOORA metotlarından Referans Nokta Teorisi kullanılmıştır. Ancak bu yaklaşımda MOORA-Oran yöntemi ile elde edilen normalleştirilmiş veriler Referans Nokta Teorisinde esas alınır. MOORA'nın bu teorisini uygularken, her kirter için; amaç maksimizasyon ise maksimum noktalar, amaç minimizasyon ise minimum noktalar olan referans noktaları belirlenir. MOORA yönteminde öncelikle çeşitli nitelikler veya amaçlara ilişkin farklı alternatiflerin performansını gösteren Eşitlik 1 de yer alan karar matrisi oluşturulmaktadır. 


$$
\mathrm{x}=\left[\begin{array}{cccc}
x_{11} & x_{12} & \cdots & x_{1 n} \\
x_{21} & x_{22} & \cdots & x_{2 n} \\
\cdot & & & \cdot \\
\cdot & & & \cdot \\
\cdot & & & \cdot \\
x_{m 1} & x_{m 2} & x_{m n}
\end{array}\right]
$$

Oran metodunda, $i=1,2,3 \ldots, \mathrm{m}$ alternatifin sayısı, $\mathrm{j}=1,2,3 \ldots \ldots, \mathrm{n}$ kriret sayısı olmak üzere her bir alternatifin karelerinin toplamının karekökü ile kriterler bölünerek normalizasyon işlemi yapılır. Yani, kriterler temelinde alternatiflerin başlangıç verileri normalize edilir. Kriter temelindeki her bir alternatif, o kriterle ilgili bütün alternatifleri temsil eden bir payda (bölen) ile karşılaştırılır. Payda, her kriterin, her bir alternatifte aldığ 1 değerlerin kareler toplamının karekökünü içerir.

$x_{i j}^{*}: i$ kriteri için $j$ alternatifinin değeri; $j=1,2, \ldots, m ; \mathrm{m}$ alternatiflerin sayısı; $i=1,2, \ldots, n ; \mathrm{n}$ kriterlerin sayısı;

$x_{i j}^{*}: i$ kriteri için $j$ alternatifinin normalize değerini ifade eden boyutsuz (ölçüleri olmayan) sayıdır. Bu işlem aşağıdaki formülle gerçekleştirilir.

$$
X_{i j}^{*}=\frac{X_{i j}}{\sqrt{\sum_{i=1}^{m} x_{i j}^{2}}}
$$

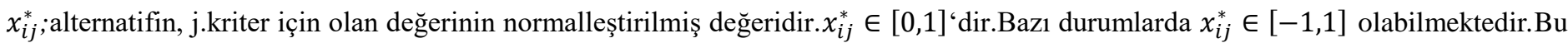
normalizasyon işleminden sonra hazırlanan tabloda kriterler maximum veya minimum olmalarına göre belirlenip toplanırlar ve toplanan maximum kriterin değerinden toplanan minimum kriter değeri çıkartılır. Yani $i=1,2, . ., g$ maksimize edilecek kriterler $j=g+1, g+2, \ldots, n$ minimimze edilecek kriterler olmak üzere şeklinde yazılabilir.

$$
y_{i}^{*}=\sum_{j=1}^{g} X_{i j}^{*}-\sum_{j=g+1}^{n} X_{i j}^{*}
$$

$y_{i}^{*} ; i$ alternatifinin tüm kriterlere göre normalleştirilmiş değerlendirilmesidir.

$y_{i}^{*}$ 'lerin sırasıyla işlem tamamlanmış olur.

Adım 1: Amaçların ve seçeneklerin performans değerlerinin belirlenmesi. Amaçların belirlenmesi ve farklı seçeneklerin farklı amaçlara göre performans değerlerinin bir matriste toplanması ile başlar.

Adım 2: Matrisin normalleştirilmesi. Matrisin normalleştirilmesi ölçütlerin maksimizasyon ya da minimizasyon yönlü olup olmadığına bakılmaksızın yapılır.

Adım 3: Normalleştirilmiş maksimizasyon performans değerleri toplamından minimizasyon performans değerleri toplamı çıkarılır.

g, maksimize edilecek amaçların sayısını, (n-g), minimize edilecek amaçların sayısını ve $y_{i}^{*}$ ise i. seçeneğin tüm amaçlara göre normalleştirilmiş değerini ifade etmektedir. $y_{i}^{*}$ değerleri büyükten küçüğe doğru sıralanır. $y_{i}^{*}$ sıralamasına göre birinci sıradaki seçenek en uygun seçenek olarak belirlenir.

\section{Referans nokta metodu:}

Referans noktası yaklaşımında seçeneklerin her bir amaca göre maksimizasyon durumunda en iyi değeri, minimizasyon durumunda ise en düşük değeri referans noktası $r_{j}$ olarak belirlenir. Belirlenen bu noktaların, $x_{i j}^{*}$ ile olan uzaklıkları bulunur. Yani,

işlemi yapılır ve matris olarak yazılır.

$$
r_{j}-x_{i j}^{*}
$$

Buradan;

$\mathrm{x}_{\mathrm{ij}}^{*}$, i. Alternatifin j. Kriterdeki normalleştirilmiş değerini,

$r_{j}, \mathrm{j}$. Kriterin referans noktasını göstermektedir.

Yeni matrise, 'Tchepycheff Min-Maks Metrik' işlemi uygulanır

$$
\min _{i}\left\{\operatorname{maks}_{j}\left(\left|r_{j}-\mathrm{x}_{\mathrm{ij}}^{*}\right|\right)\right\} .
$$

\section{Araştırma Sonuçları ve Tartışma}

\subsection{TOPSIS ve MOORA Analiz Sonuçları}

36 ülkenin ve Avrupa Birliği'nin ortalama değerlerinin yer aldığı, toplam 10 kriter eşit ağırlıklı olarak kabul edilerek ve 37 alternatifin yer aldığı matris oluşturularak ve 2018 yılı Avrupa İnovasyon Endeski skorları baz alınarak yapılan çalışmada TOPSIS analizi sonuçları Tablo.2'de sunulmuştur. Araştırmada kullanılan Avrupa İnovasyon Performanslarının Skorları 2018 yılı verileri Tablo 5.'te yer almaktadir. 
Tablo 2. TOPSIS Analizi Sonuçları

\begin{tabular}{|c|l|c|c|c|c|c|l|c|c|c|c|}
\hline NO & ÜLKELER & di- & di+ & ci & SIra & NO & ÜLKELER & di- & di+ & ci & SIra \\
\hline 1 & İsiçre & 0,08 & 0,02 & 0,8365 & 1 & 20 & Çekya & 0,04 & 0,05 & 0,4235 & 20 \\
\hline 2 & İsveç & 0,07 & 0,02 & 0,7635 & 2 & 21 & Estonya & 0,04 & 0,05 & 0,4185 & 21 \\
\hline 3 & Danimarka & 0,07 & 0,03 & 0,692 & 3 & 22 & İspanya & 0,04 & 0,05 & 0,4149 & 22 \\
\hline 4 & Finlandiya & 0,06 & 0,03 & 0,6841 & 4 & 23 & Klbrls & 0,04 & 0,06 & 0,3847 & 23 \\
\hline 5 & Hollanda & 0,06 & 0,03 & 0,6738 & 5 & 24 & Littvanya & 0,04 & 0,06 & 0,3798 & 24 \\
\hline 6 & Izlanda & 0,06 & 0,04 & 0,6375 & 6 & 25 & Italya & 0,03 & 0,06 & 0,3768 & 25 \\
\hline 7 & Luxemburg & 0,06 & 0,03 & 0,6374 & 7 & 26 & Macaristan & 0,03 & 0,06 & 0,3512 & 26 \\
\hline 8 & Birleşik Krallık & 0,06 & 0,03 & 0,6289 & 8 & 27 & Strbistan & 0,03 & 0,06 & 0,3346 & 27 \\
\hline 9 & Almanya & 0,06 & 0,03 & 0,6269 & 9 & 28 & Yunanistan & 0,03 & 0,06 & 0,3321 & 28 \\
\hline 10 & Belçika & 0,06 & 0,04 & 0,6112 & 10 & 29 & Slovakya & 0,03 & 0,06 & 0,3304 & 29 \\
\hline 11 & Norveç & 0,06 & 0,04 & 0,6003 & 11 & 30 & Letonya & 0,03 & 0,06 & 0,3255 & 30 \\
\hline 12 & Avustuya & 0,06 & 0,04 & 0,5971 & 12 & 31 & Türkiye & 0,03 & 0,07 & 0,3132 & 31 \\
\hline 13 & Israil & 0,06 & 0,04 & 0,5933 & 13 & 32 & Polonya & 0,03 & 0,07 & 0,2922 & 32 \\
\hline 14 & Irlanda & 0,06 & 0,04 & 0,5894 & 14 & 33 & Hirvatistan & 0,02 & 0,07 & 0,2663 & 33 \\
\hline 15 & Fransa & 0,05 & 0,04 & 0,5741 & 15 & 34 & Bulgaristan & 0,02 & 0,07 & 0,2529 & 34 \\
\hline 16 & Avrupa Birliği Ort. & 0,05 & 0,04 & 0,5279 & 16 & 35 & Makedonya & 0,02 & 0,07 & 0,1957 & 35 \\
\hline 17 & Slovenya & 0,04 & 0,05 & 0,4701 & 17 & 36 & Ukrayna & 0,02 & 0,08 & 0,1955 & 36 \\
\hline 18 & Malta & 0,05 & 0,06 & 0,4492 & 18 & 37 & Romanya & 0,02 & 0,08 & 0,1614 & 37 \\
\hline 19 & Portekiz & 0,04 & 0,05 & 0,429 & 19 & & & & & & \\
\hline
\end{tabular}

Tablo 2'da görüldüğü üzere her bir karar noktasının ideal çözüme yakınlığının hesaplanmasında ideal ve ideal olmayan uzaklıklardan yararlanılmış ve ideal çözüme yakınlık değerleri tespit edilmiştir. Buradan anlaşılacağı üzere, TOPSIS metodu uygulaması sonucu ülkelerin inovasyon performans sıralamasında en iyi puanlamaya sahip ilk üç ülke sırasıyla; AB üyesi olmayan İsviçre, AB üyesi ve 'İnvoasyonda Lider' ülkelerden olan İsveç ve Finlandiya'dır. Bu değerlendirmeye göre son üç ülke ise Ukrayna, Romanya ve aday ülkelerden Makedonya'dır. Türkiye ise bu sıralamada gerilerde kalmış olup, 31. sırada yer almaktadır. Aslında bu sıralamada yer alan AB'ye üye Sırbistan, Bulgaristan, Polonya, Hırvatistan gibi ülkelerden Türkiye'nin daha iyi olduğu gözlemlenmektedir. MOORA analizi sonuçları ise Tablo.3'de yer almaktadır.

Tablo 3. MOORA Analizi Sonuçları

\begin{tabular}{|c|c|c|c|c|c|c|c|}
\hline NO & $\ddot{U L K E L E R}$ & $\begin{array}{c}\text { MAKSIMUM } \\
\text { REFERANS } \\
\text { NOKTASI }\end{array}$ & $\begin{array}{l}\text { Referans Nokta } \\
\text { Yak. Siralama }\end{array}$ & NO & $\ddot{U} L K E L E R$ & $\begin{array}{c}\text { MAKSIMUM } \\
\text { REFERANS } \\
\text { NOKTASI }\end{array}$ & $\begin{array}{c}\text { Referans Nokta } \\
\text { Yak. Siralama }\end{array}$ \\
\hline 1 & İsveç & 0,10 & 1 & 20 & Ispanya & 0,23 & 20 \\
\hline 2 & İsviçre & 0,10 & 2 & 21 & Italya & 0,25 & 21 \\
\hline 3 & Danimarka & 0,16 & 3 & 22 & Yunanistan & 0,25 & 22 \\
\hline 4 & Finlandiya & 0,16 & 4 & 23 & Estonya & 0,25 & 23 \\
\hline 5 & Birleşik Krallık & 0,17 & 5 & 24 & Slovakya & 0,25 & 24 \\
\hline 6 & Israil & 0,17 & 6 & 25 & Malta & 0,26 & 25 \\
\hline 7 & Avusturya & 0,17 & 7 & 26 & Sirbistan & 0,26 & 26 \\
\hline 8 & Belçika & 0,18 & 8 & 27 & Kıbris & 0,27 & 27 \\
\hline 9 & Avrupa Birliği Ort. & 0,18 & 9 & 28 & Hirvatistan & 0,27 & 28 \\
\hline 10 & Irlanda & 0,18 & 10 & 29 & Macaristan & 0,27 & 29 \\
\hline 11 & Almanya & 0,18 & 11 & 30 & Letonya & 0,27 & 30 \\
\hline 12 & Izlanda & 0,19 & 12 & 31 & Litvanya & 0,27 & 31 \\
\hline 13 & Slovenya & 0,19 & 13 & 32 & Bulgaristan & 0,28 & 32 \\
\hline 14 & Fransa & 0,19 & 14 & 33 & Türkiye & 0,28 & 33 \\
\hline 15 & Norveç & 0,20 & 15 & 34 & Makedonya & 0,29 & 34 \\
\hline 16 & Cekya & 0,21 & 16 & 35 & Polonya & 0,29 & 35 \\
\hline 17 & Luxemburg & 0,22 & 17 & 36 & Ukrayna & 0,30 & 36 \\
\hline 18 & Portekiz & 0,22 & 18 & 37 & Romanya & 0,32 & 37 \\
\hline 19 & Hollanda & 0,22 & 19 & & & & \\
\hline
\end{tabular}

Tablo 3'de sunulan MOORA yöntemi sonuçlarına göre ilk üç sırada sırasıyla, İsveç, İsviçre ve Danimarka' nın yer aldığı görünmektedir. Son üç sırada ise, AB üyesi Romanya, komşu ülke Ukrayna ve yine bir AB ülkesi olan Polonya bulunmaktadır. Türkiye sıralamada, 33. Sırada yer alarak inovasyon performansı oldukça gerilerde kalmıştır.

Her iki yönteme göre hesaplanan ülke skorları bu bölümde inovasyon endeksi değerleriyle karşılaştırılmıştır. Sonuçların normal dağıldığı görülmüşs olup, sonuçların birbirleriyle ilişkili olup olmadığını belirlemek amacıyla Pearson korelasyon analizi yapılmıştır. e-ISSN: 2148-2683 
Korelasyon katsayısı $[-1 ;+1]$ aralığında değer almaktadır. İnovasyon endeksi sonucu değeri ve MOORA Topsis yöntemleri sonucu elde edilen skorların korelasyon katsayıları Tablo 4'te hesaplanmıştır. Buna göre TOPSIS yöntemiyle elde edilen inovasyon endeksi skorları ile MOORA yöntemiyle elde edilen inovasyon endeksi skorları karşılaştırıldığında korelasyon katsayısı $-0,929$ olarak hesaplanmıştır. İki yöntem arasında ters yönlü çok güçlü bir ilişsi olduğu görülmüştür. Sonuç olarak elde edilen katsayıların her iki yöntemde de birbiriyle çok güçlü ilişkili olması, sıralamaların yöntemler arasında da benzerlik gösterdiği şeklinde yorumlanabilir.

Tablo 4. Çok Nitelikli Karar Verme Teknikleri Çıktılarının Inovasyon Endeksi Karşılaştırmasında Korelasyon Katsayıları

\begin{tabular}{|c|c|}
\hline Pearson Correlation &,$- 929 * *$ \\
\hline Sig. (2-tailed) &, 000 \\
\hline N & 36 \\
\hline
\end{tabular}

\section{Sonuç}

Avrupa İnovasyon Endeksi'ne ve bu endekste yer alan değişkenlerin seviyelerine göre ülkelerinin inovasyon performansları ekonomi açısından büyük önem taşımaktadır. Bu değerlere göre ülkelerin gelişmişlik ve inovatif düzeyleri hakkında bilgi edinilmektedir. Dünyada ülkelerin rekabetçi olması, verim, ürün ve hizmet kalitesinin yüksek olmasıyla birlikte satış etkinliği, istihdam edilen personellerin niteliği ve gelişimi, araştırma sistemleri, sağlanan finansman ve destekler, yapılan yenilikler ve sunulan ortamlar yenilikler gibi birçok kritere bağlıdır. Ülkelerin inovasyona yönelik mevcut durumlarını analiz ederek, iyileştirmeleri gereken kriterleri önceliklendirmleri gerekmektedir. Ancak bu sayede uluslararası platformlarda rekabet edebilir düzeye ulaşabileceklerdir.

$\mathrm{Bu}$ araştırmanın amacı; çok kriterli karar verme yöntemlerinden TOPSIS ve MOORA yöntemleri kullanılarak Avrupa Birliği’ne üye olan 28 ülke, Türkiye'nin de aralarında bulunduğu 3 aday, 5 komşu ülke ve Avrupa Birliği ortalamasını da içerek şekilde ülkelerin inovasyon performansının kıyaslanmasıdır. Bu kapsamda 2018 yılı Avrupa İnovasyon Endeksi verileri kullanılmıştır. Yapılan analizlerin sonuçlarına göre her iki yöntemde de performans düzeyi en yüksek olan üç ülke İsveç, İsviçre ve Danimarka olarak tespit edilmiştir. Son üç ülkeye bakıldığında ise TOPSIS yöntemine göre Romanya, Makedonya ve Ukrayna, MOORA yöntemine göre ise son üç ülke arasında Ukrayna yerine Polonya görülmektedir. Avrupa İnovasyon Endeksi'ne göre verileri incelendiğinde Türkiye'nin sıralamalardaki yerine bakıldığında; TOPSIS Yöntemi’ne göre 31. Sırada, MOORA Yöntemi'ne göre ise 32. sırada yer almaktadır. Türkiye'nin inovasyon performansında alt sıralarda yer almasında ana ve ana göstergeleri oluşturan alt göstergeler incelenmelidir. Analiz kapsamında ele alınan temel göstergelerden insan kaynaklarında 35., entelektüel varlıklarda 36. ve satışın etkilerinde 35. sırada yer alarak ülke sıralamalarında gerilerde kaldığı görülmektedir. Bu göstergelerin alt kriterlerini ise doktora mezunu sayısı, yükseköğrenimdeki öğrenci popülasyonu ve hayat boyu öğrenme prosesi, paternt uygulamaları, ticari marka uygulamaları, tasarım uygulamaları, orta ve ileri seviye teknoloji ürünlerinin ihracı, bilgi yoğun hizmetlerin ihracı ve yeni pazar-firma yeniliklerinin satışı oluşturmaktadır. $\mathrm{Bu}$ alt başlıklara özellikle odaklanılarak iyileştirilmesi için efor sarf edilmelidir. Türkiye'nin inovasyon performansına alt kriter bazlı sıralamalarda bakıldığında ise; ilk on ülke arasında olduğu tek temel kriter 'firma yatırımları' olmuştur. Firma yatırımlarının alt göstergeleri ise özel sektördeki Ar-Ge harcamaları, Ar-Ge dışı harcamalari ve bilgi, iletişim, teknoloji eğitimi veren kurumlar olarak belirtilmektedir. Bu doğrultuda ülke sıralamalarına göre Türkiye'nin inovasyon performansının arttırması için inovasyon performansını oluşturan tüm kriterlere ağırlık vermesi gerektiği görülmüştür. Öncelik vermesi gereken alt göstergeler ise doktora mezunu sayısı, yükseköğrenimdeki öğrenci popülasyonu ve hayat boyu öğrenme prosesi, patent uygulamaları, ticari marka uygulamaları, tasarım uygulamaları, orta ve ileri seviye teknoloji ürünlerinin ihracı, bilgi yoğun hizmetlerin ihracı ve yeni pazar-firma yeniliklerinin satışı kriterleridir.

Ayrıca, Türkiye açısından ele alındığında, bu tarz çalışmaların artması, özellikle inovasyon konusunda sadece Avrupa ülkeleri ile değil küresel çapta alanında en iyi ülkelerle yapılacak kıyaslamalarla mevcut durum tespitlerinin yapılması, hangi parametrelerde eksiklerin olduğu daha detaylı bir şekilde tespit edilmelidir. Bu konuda oluşturulacak bir ulusal inovasyon stratejisi ekonomik ve toplumsal hedeflere ulaşmada ivme kazandıracaktır. 
Tablo 5. Avrupa Inovasyon Performanslarının Skorları 2018 Yılı Tablosu

\begin{tabular}{|c|c|c|c|c|c|c|c|c|c|c|c|}
\hline NO & ÜLKELER & IK & AS & YO & FD & FY & $\mathbf{Y}$ & B & EV & IE & SE \\
\hline 1 & $A B$ & 119,3 & 113,6 & 133,8 & 107,7 & 111,8 & 86,0 & 101,0 & 100,9 & 100,6 & 104,1 \\
\hline 2 & Belçilka & 127,1 & 191,0 & 143,5 & 107,4 & 149,5 & 138,8 & 163,4 & 84,3 & 78,9 & 78,3 \\
\hline 3 & Bulgaristan & 64,7 & 31,8 & 70,7 & 22,7 & 57,5 & 12,3 & 32,3 & 86,6 & 103,0 & 34,3 \\
\hline 4 & Çekya & 93,5 & 82,4 & 106,0 & 50,9 & 116,2 & 74,1 & 78,4 & 63,2 & 115,7 & 98,7 \\
\hline 5 & Danimarka & 219,8 & 206,4 & 264,6 & 110,5 & 122,0 & 96,3 & 132,6 & 167,3 & 101,0 & 78,2 \\
\hline 6 & Almanya & 112,6 & 104,8 & 134,7 & 109,8 & 174,8 & 131,3 & 126,4 & 148,9 & 100,9 & 119,4 \\
\hline 7 & Estonya & 123,9 & 101,8 & 138,9 & 96,5 & 75,4 & 24,3 & 76,3 & 111,6 & 74,9 & 65,4 \\
\hline 8 & Irlanda & 167,9 & 160,8 & 129,3 & 81,6 & 104,5 & 146,3 & 90,0 & 47,3 & 165,7 & 132,9 \\
\hline 9 & Yunanistan & 84,4 & 102,3 & 54,0 & 41,7 & 61,2 & 101,3 & 91,1 & 35,4 & 69,2 & 47,4 \\
\hline 10 & $\dot{I}$ spanya & 141,6 & 98,7 & 143,5 & 86,4 & 75,8 & 36,2 & 69,3 & 72,9 & 90,7 & 76,6 \\
\hline 11 & Fransa & 148,5 & 146,8 & 135,8 & 152,2 & 97,9 & 104,4 & 102,4 & 86,8 & 92,5 & 109,6 \\
\hline 12 & Hirvatistan & 53,7 & 42,3 & 54,4 & 40,2 & 108,1 & 62,0 & 67,2 & 29,8 & 69,0 & 26,7 \\
\hline 13 & Italya & 65,2 & 99,4 & 84,6 & 59,4 & 64,5 & 90,8 & 57,1 & 104,3 & 74,8 & 77,0 \\
\hline 14 & Klbrls & 114,2 & 118,7 & 61,0 & 45,8 & 60,6 & 87,0 & 60,4 & 115,5 & 61,1 & 76,1 \\
\hline 15 & Letonya & 79,8 & 55,8 & 141,2 & 107,4 & 37,5 & 12,7 & 44,3 & 48,8 & 94,1 & 46,3 \\
\hline 16 & Litvanya & 115,5 & 39,5 & 164,5 & 64,0 & 104,2 & 79,7 & 103,0 & 51,5 & 39,6 & 36,6 \\
\hline 17 & Luxemburg & 150,3 & 224,8 & 192,0 & 134,3 & 77,1 & 122,3 & 62,8 & 154,4 & 139,4 & 88,2 \\
\hline 18 & Macaristan & 54,6 & 66,4 & 117,9 & 50,0 & 87,5 & 15,1 & 70,2 & 39,5 & 124,9 & 99,0 \\
\hline 19 & Malta & 66,5 & 161,0 & 165,4 & 7,5 & 79,8 & 67,9 & 11,9 & 168,3 & 140,5 & 56,8 \\
\hline 20 & Hollanda & 174,4 & 207,5 & 213,3 & 140,2 & 85,4 & 109,5 & 152,6 & 127,7 & 115,9 & 95,5 \\
\hline 21 & Avusturya & 134,6 & 157,4 & 116,0 & 98,8 & 150,7 & 122,1 & 144,9 & 147,5 & 66,0 & 82,8 \\
\hline 22 & Polanya & 72,2 & 33,4 & 127,2 & 33,2 & 90,6 & 2,9 & 37,9 & 75,2 & 92,5 & 55,3 \\
\hline 23 & Portekiz & 100,0 & 120,9 & 178,2 & 70,1 & 83,5 & 99,9 & 54,9 & 74,0 & 82,8 & 44,9 \\
\hline 24 & Romanya & 22,5 & 29,7 & 96,8 & 22,4 & 13,3 & 0,0 & 38,1 & 22,5 & 34,7 & 66,6 \\
\hline 25 & Slovenya & 171,4 & 102,5 & 117,3 & 36,0 & 135,3 & 82,2 & 113,4 & 80,9 & 75,8 & 78,1 \\
\hline 26 & Slovakya & 92,6 & 57,4 & 79,3 & 29,7 & 63,7 & 29,2 & 68,7 & 35,6 & 119,2 & 105,4 \\
\hline 27 & Finlandiya & 197,1 & 156,6 & 245,7 & 118,7 & 148,1 & 121,7 & 133,9 & 148,1 & 83,9 & 80,8 \\
\hline 28 & İsveç & 214,3 & 200,6 & 254,8 & 120,1 & 176,5 & 109,1 & 132,3 & 158,0 & 132,1 & 85,5 \\
\hline 29 & Birleşik Krallık & 180,6 & 196,8 & 123,4 & 115,8 & 113,9 & 85,6 & 134,8 & 82,3 & 144,8 & 128,3 \\
\hline 30 & Izlanda & 150,3 & 188,1 & 264,6 & 122,3 & 134,5 & 123,6 & 158,2 & 57,8 & 147,1 & 36,6 \\
\hline 31 & Israil & 105,1 & 130,6 & 112,3 & 45,6 & 243,9 & 74,6 & 141,2 & 103,2 & 186,1 & 95,9 \\
\hline 32 & Makedonya & 42,8 & 76,2 & 53,7 & 32,8 & 69,7 & 55,0 & 44,1 & 14,3 & 6,5 & 46,3 \\
\hline 33 & Norveç & 171,1 & 166,4 & 192,7 & 147,0 & 139,6 & 119,7 & 137,5 & 45,2 & 95,4 & 51,9 \\
\hline 34 & Sirbistan & 76,5 & 37,2 & 24,8 & 40,6 & 132,3 & 72,3 & 94,9 & 24,4 & 94,0 & 60,9 \\
\hline 35 & İsviçre & 236,4 & 251,6 & 193,9 & 126,4 & 234,8 & 160,7 & 142,1 & 164,7 & 118,1 & 114,6 \\
\hline 36 & Ukrayna & 131,6 & 22,3 & 5,5 & 16,7 & 44,8 & 16,0 & 9,6 & 13,4 & 77,9 & 32,8 \\
\hline 37 & Türkiye & 37,5 & 43,3 & 112,5 & 56,7 & 140,8 & 83,8 & 64,3 & 9,0 & 10,8 & 55,9 \\
\hline
\end{tabular}


European Journal of Science and Technology

Tablo 6. Normalize Matrisin Elde Edilmesi

\begin{tabular}{|c|c|c|c|c|c|c|c|c|c|c|c|}
\hline NO & ÜLKELER & IK & AS & YO & FD & FY & $\mathbf{Y}$ & B & EV & IE & SE \\
\hline 1 & Avrupa Birliği & 0,15 & 0,15 & 0,15 & 0,17 & 0,16 & 0,15 & 0,17 & 0,17 & 0,16 & 0,21 \\
\hline 2 & Belçika & 0,15 & 0,25 & 0,17 & 0,18 & 0,21 & 0,25 & 0,29 & 0,15 & 0,12 & 0,16 \\
\hline 3 & Bulgaristan & 0,09 & 0,04 & 0,09 & 0,03 & 0,08 & 0,02 & 0,03 & 0,17 & 0,16 & 0,07 \\
\hline 4 & Çekya & 0,12 & 0,11 & 0,12 & 0,16 & 0,16 & 0,13 & 0,11 & 0,11 & 0,15 & 0,20 \\
\hline 5 & Danimarka & 0,28 & 0,26 & 0,29 & 0,24 & 0,17 & 0,17 & 0,21 & 0,26 & 0,16 & 0,16 \\
\hline 6 & Almanya & 0,15 & 0,14 & 0,14 & 0,21 & 0,25 & 0,24 & 0,24 & 0,23 & 0,16 & 0,24 \\
\hline 7 & Estonya & 0,15 & 0,12 & 0,14 & 0,26 & 0,11 & 0,04 & 0,11 & 0,17 & 0,11 & 0,13 \\
\hline 8 & Irlanda & 0,19 & 0,19 & 0,14 & 0,12 & 0,16 & 0,26 & 0,13 & 0,11 & 0,27 & 0,27 \\
\hline 9 & Yunanistan & 0,11 & 0,13 & 0,04 & 0,10 & 0,09 & 0,18 & 0,15 & 0,07 & 0,11 & 0,10 \\
\hline 10 & İspanya & 0,15 & 0,12 & 0,16 & 0,13 & 0,11 & 0,06 & 0,10 & 0,14 & 0,12 & 0,17 \\
\hline 11 & Fransa & 0,19 & 0,19 & 0,15 & 0,20 & 0,14 & 0,19 & 0,17 & 0,15 & 0,15 & 0,22 \\
\hline 12 & Hurvatistan & 0,10 & 0,05 & 0,06 & 0,11 & 0,15 & 0,11 & 0,09 & 0,07 & 0,10 & 0,05 \\
\hline 13 & Italya & 0,09 & 0,12 & 0,09 & 0,10 & 0,09 & 0,16 & 0,08 & 0,18 & 0,11 & 0,16 \\
\hline 14 & Kıbris & 0,14 & 0,15 & 0,07 & 0,10 & 0,07 & 0,16 & 0,08 & 0,19 & 0,10 & 0,13 \\
\hline 15 & Letonya & 0,12 & 0,05 & 0,20 & 0,16 & 0,06 & 0,02 & 0,08 & 0,09 & 0,13 & 0,10 \\
\hline 16 & Littvanya & 0,15 & 0,04 & 0,18 & 0,20 & 0,14 & 0,14 & 0,20 & 0,09 & 0,11 & 0,07 \\
\hline 17 & Luxemburg & 0,18 & 0,28 & 0,22 & 0,14 & 0,11 & 0,22 & 0,08 & 0,29 & 0,22 & 0,19 \\
\hline 18 & Macaristan & 0,08 & 0,07 & 0,12 & 0,09 & 0,12 & 0,03 & 0,11 & 0,08 & 0,20 & 0,20 \\
\hline 19 & Malta & 0,08 & 0,11 & 0,14 & 0,05 & 0,09 & 0,12 & 0,03 & 0,28 & 0,25 & 0,10 \\
\hline 20 & Hollanda & 0,21 & 0,26 & 0,21 & 0,24 & 0,11 & 0,20 & 0,29 & 0,19 & 0,20 & 0,19 \\
\hline 21 & Avustuya & 0,17 & 0,20 & 0,14 & 0,20 & 0,23 & 0,22 & 0,24 & 0,24 & 0,12 & 0,17 \\
\hline 22 & Polonya & 0,10 & 0,04 & 0,11 & 0,11 & 0,12 & 0,00 & 0,05 & 0,13 & 0,14 & 0,11 \\
\hline 23 & Portekiz & 0,14 & 0,15 & 0,20 & 0,17 & 0,12 & 0,18 & 0,07 & 0,13 & 0,11 & 0,09 \\
\hline 24 & Romanya & 0,06 & 0,04 & 0,11 & 0,04 & 0,02 & - & 0,05 & 0,04 & 0,06 & 0,13 \\
\hline 25 & Slovenya & 0,21 & 0,13 & 0,15 & 0,08 & 0,20 & 0,14 & 0,19 & 0,16 & 0,12 & 0,16 \\
\hline 26 & Slovakya & 0,12 & 0,07 & 0,09 & 0,15 & 0,10 & 0,05 & 0,11 & 0,07 & 0,18 & 0,22 \\
\hline 27 & Finlandiya & 0,25 & 0,20 & 0,25 & 0,26 & 0,20 & 0,22 & 0,23 & 0,23 & 0,13 & 0,15 \\
\hline 28 & İsveç & 0,28 & 0,25 & 0,28 & 0,25 & 0,24 & 0,20 & 0,21 & 0,23 & 0,22 & 0,18 \\
\hline 29 & Birleşik Krallık & 0,23 & 0,25 & 0,13 & 0,18 & 0,17 & 0,15 & 0,23 & 0,15 & 0,24 & 0,27 \\
\hline 30 & Izlanda & 0,19 & 0,24 & 0,29 & 0,26 & 0,20 & 0,23 & 0,27 & 0,13 & 0,24 & 0,09 \\
\hline 31 & Israil & 0,13 & 0,17 & 0,13 & 0,10 & 0,34 & 0,13 & 0,17 & 0,23 & 0,30 & 0,20 \\
\hline 32 & Makedonya & 0,06 & 0,03 & 0,08 & 0,01 & 0,10 & 0,12 & 0,08 & 0,02 & 0,01 & 0,15 \\
\hline 33 & Norveç & 0,22 & 0,21 & 0,26 & 0,22 & 0,19 & 0,22 & 0,22 & 0,09 & 0,17 & 0,10 \\
\hline 34 & Surbistan & 0,10 & 0,06 & 0,05 & 0,09 & 0,18 & 0,15 & 0,08 & 0,04 & 0,15 & 0,13 \\
\hline 35 & İsviçre & 0,30 & 0,32 & 0,20 & 0,22 & 0,30 & 0,29 & 0,28 & 0,26 & 0,20 & 0,23 \\
\hline 36 & Ukrayna & 0,08 & 0,02 & - & 0,04 & 0,07 & 0,03 & 0,01 & 0,04 & 0,12 & 0,07 \\
\hline 37 & Türkiye & 0,06 & 0,04 & 0,14 & 0,15 & 0,20 & 0,15 & 0,11 & 0,04 & 0,02 & 0,10 \\
\hline
\end{tabular}


Tablo. 7 MOORA Yöntemine Göre Toplam Performans Değeri Hesaplama

\begin{tabular}{|c|c|c|c|c|c|c|c|c|c|c|c|}
\hline NO & ÜLKELER & IK & AS & YO & FD & FY & $\mathbf{Y}$ & B & EV & IE & SE \\
\hline 1 & Avrupa Birliği & 0,15 & 0,14 & 0,15 & 0,20 & 0,16 & 0,16 & 0,17 & 0,17 & 0,16 & 0,21 \\
\hline 2 & Belçika & 0,16 & 0,24 & 0,16 & 0,20 & 0,21 & 0,25 & 0,27 & 0,14 & 0,13 & 0,16 \\
\hline 3 & Bulgaristan & 0,08 & 0,04 & 0,08 & 0,04 & 0,08 & 0,02 & 0,05 & 0,15 & 0,17 & 0,07 \\
\hline 4 & Çekya & 0,12 & 0,10 & 0,12 & 0,10 & 0,16 & 0,13 & 0,13 & 0,11 & 0,19 & 0,20 \\
\hline 5 & Danimarka & 0,28 & 0,26 & 0,29 & 0,21 & 0,17 & 0,17 & 0,22 & 0,28 & 0,16 & 0,16 \\
\hline 6 & Almanya & 0,14 & 0,13 & 0,15 & 0,21 & 0,24 & 0,24 & 0,21 & 0,25 & 0,16 & 0,25 \\
\hline 7 & Estonya & 0,16 & 0,13 & 0,15 & 0,18 & 0,11 & 0,04 & 0,13 & 0,19 & 0,12 & 0,13 \\
\hline 8 & Irlanda & 0,21 & 0,20 & 0,14 & 0,15 & 0,15 & 0,27 & 0,15 & 0,08 & 0,27 & 0,27 \\
\hline 9 & Yunanistan & 0,11 & 0,13 & 0,06 & 0,08 & 0,09 & 0,18 & 0,15 & 0,06 & 0,11 & 0,10 \\
\hline 10 & İspanya & 0,18 & 0,12 & 0,16 & 0,16 & 0,11 & 0,07 & 0,11 & 0,12 & 0,15 & 0,16 \\
\hline 11 & Fransa & 0,19 & 0,18 & 0,15 & 0,29 & 0,14 & 0,19 & 0,17 & 0,15 & 0,15 & 0,23 \\
\hline 12 & Hirvatistan & 0,07 & 0,05 & 0,06 & 0,08 & 0,15 & 0,11 & 0,11 & 0,05 & 0,11 & 0,05 \\
\hline 13 & Italya & 0,08 & 0,12 & 0,09 & 0,11 & 0,09 & 0,16 & 0,09 & 0,18 & 0,12 & 0,16 \\
\hline 14 & Kibris & 0,14 & 0,15 & 0,07 & 0,09 & 0,08 & 0,16 & 0,10 & 0,20 & 0,10 & 0,16 \\
\hline 15 & Letonya & 0,10 & 0,07 & 0,16 & 0,20 & 0,05 & 0,02 & 0,07 & 0,08 & 0,15 & 0,10 \\
\hline 16 & Litvanya & 0,15 & 0,05 & 0,18 & 0,12 & 0,15 & 0,14 & 0,17 & 0,09 & 0,06 & 0,08 \\
\hline 17 & Luxemburg & 0,19 & 0,28 & 0,21 & 0,25 & 0,11 & 0,22 & 0,10 & 0,26 & 0,22 & 0,18 \\
\hline 18 & Macaristan & 0,07 & 0,08 & 0,13 & 0,09 & 0,12 & 0,03 & 0,12 & 0,07 & 0,20 & 0,20 \\
\hline 19 & Malta & 0,08 & 0,20 & 0,18 & 0,01 & 0,11 & 0,12 & 0,02 & 0,29 & 0,23 & 0,12 \\
\hline 20 & Hollanda & 0,22 & 0,26 & 0,24 & 0,26 & 0,12 & 0,20 & 0,25 & 0,22 & 0,19 & 0,20 \\
\hline 21 & Avusturya & 0,17 & 0,19 & 0,13 & 0,19 & 0,21 & 0,22 & 0,24 & 0,25 & 0,11 & 0,17 \\
\hline 22 & Polonya & 0,09 & 0,04 & 0,14 & 0,06 & 0,13 & 0,01 & 0,06 & 0,13 & 0,15 & 0,11 \\
\hline 23 & Portekiz & 0,13 & 0,15 & 0,20 & 0,13 & 0,12 & 0,18 & 0,09 & 0,13 & 0,13 & 0,09 \\
\hline 24 & Romanya & 0,03 & 0,04 & 0,11 & 0,04 & 0,02 & - & 0,06 & 0,04 & 0,06 & 0,14 \\
\hline 25 & Slovenya & 0,22 & 0,13 & 0,13 & 0,07 & 0,19 & 0,15 & 0,19 & 0,14 & 0,12 & 0,16 \\
\hline 26 & Slovakya & 0,12 & 0,07 & 0,09 & 0,06 & 0,09 & 0,05 & 0,11 & 0,06 & 0,19 & 0,22 \\
\hline 27 & Finlandiya & 0,25 & 0,19 & 0,27 & 0,22 & 0,21 & 0,22 & 0,22 & 0,25 & 0,13 & 0,17 \\
\hline 28 & İsveç & 0,27 & 0,25 & 0,28 & 0,23 & 0,25 & 0,20 & 0,22 & 0,27 & 0,21 & 0,18 \\
\hline 29 & Birleşik Krallık & 0,23 & 0,24 & 0,14 & 0,22 & 0,16 & 0,16 & 0,22 & 0,14 & 0,23 & 0,26 \\
\hline 30 & Izlanda & 0,19 & 0,23 & 0,29 & 0,23 & 0,19 & 0,22 & 0,26 & 0,10 & 0,24 & 0,08 \\
\hline 31 & Israil & 0,13 & 0,16 & 0,12 & 0,09 & 0,34 & 0,14 & 0,23 & 0,18 & 0,30 & 0,20 \\
\hline 32 & Makedonya & 0,05 & 0,09 & 0,06 & 0,06 & 0,10 & 0,10 & 0,07 & 0,02 & 0,01 & 0,10 \\
\hline 33 & Norveç & 0,22 & 0,21 & 0,21 & 0,28 & 0,19 & 0,22 & 0,23 & 0,08 & 0,15 & 0,11 \\
\hline 34 & Surbistan & 0,10 & 0,05 & 0,03 & 0,08 & 0,18 & 0,13 & 0,16 & 0,04 & 0,15 & 0,13 \\
\hline 35 & İsviçre & 0,30 & 0,31 & 0,22 & 0,24 & 0,33 & 0,29 & 0,23 & 0,28 & 0,19 & 0,24 \\
\hline 36 & Ukrayna & 0,17 & 0,03 & 0,01 & 0,03 & 0,06 & 0,03 & 0,02 & 0,02 & 0,12 & 0,07 \\
\hline 37 & Türkiye & 0,05 & 0,05 & 0,13 & 0,11 & 0,20 & 0,15 & 0,11 & 0,02 & 0,02 & 0,11 \\
\hline
\end{tabular}


Tablo 8. MOORA Yöntemine Göre Toplam Performans Değerlerinin Stralanması

\begin{tabular}{|c|c|c|c|c|c|c|c|c|c|c|c|c|c|}
\hline NO & ÜLKELER & IK & AS & YO & FD & FY & $\mathbf{Y}$ & B & EV & IE & SE & IK & $\begin{array}{l}\text { Referans } \\
\text { Nok.Yak. }\end{array}$ \\
\hline 1 & Avrupa Birliği & 0,15 & 0,17 & 0,15 & 0,08 & 0,18 & 0,14 & 0,10 & 0,11 & 0,14 & 0,06 & 0,18 & 8 \\
\hline 2 & Belçika & 0,14 & 0,08 & 0,13 & 0,08 & 0,13 & 0,04 & - & 0,14 & 0,17 & 0,11 & 0,17 & 5 \\
\hline 3 & Bulgaristan & 0,22 & 0,27 & 0,22 & 0,24 & 0,26 & 0,27 & 0,22 & 0,14 & 0,13 & 0,20 & 0,27 & 30 \\
\hline 4 & Çekya & 0,18 & 0,21 & 0,18 & 0,19 & 0,18 & 0,16 & 0,14 & 0,18 & 0,11 & 0,07 & 0,21 & 15 \\
\hline 5 & Danimarka & 0,02 & 0,06 & - & 0,08 & 0,17 & 0,12 & 0,05 & 0,00 & 0,14 & 0,11 & 0,17 & 4 \\
\hline 6 & Almanya & 0,16 & 0,18 & 0,14 & 0,08 & 0,10 & 0,05 & 0,06 & 0,03 & 0,14 & 0,03 & 0,18 & 7 \\
\hline 7 & Estonya & 0,14 & 0,19 & 0,14 & 0,10 & 0,23 & 0,25 & 0,14 & 0,10 & 0,18 & 0,14 & 0,25 & 21 \\
\hline 8 & Irlanda & 0,09 & 0,11 & 0,15 & 0,13 & 0,19 & 0,03 & 0,12 & 0,21 & 0,03 & - & 0,21 & 13 \\
\hline 9 & Yunanistan & 0,19 & 0,18 & 0,23 & 0,21 & 0,25 & 0,11 & 0,12 & 0,23 & 0,19 & 0,18 & 0,25 & 24 \\
\hline 10 & Ispanya & 0,12 & 0,19 & 0,13 & 0,12 & 0,23 & 0,23 & 0,15 & 0,16 & 0,15 & 0,12 & 0,23 & 19 \\
\hline 11 & Fransa & 0,11 & 0,13 & 0,14 & - & 0,20 & 0,10 & 0,10 & 0,14 & 0,15 & 0,05 & 0,20 & 12 \\
\hline 12 & Hirvatistan & 0,23 & 0,26 & 0,23 & 0,21 & 0,19 & 0,18 & 0,16 & 0,24 & 0,19 & 0,22 & 0,26 & 26 \\
\hline 13 & Italya & 0,22 & 0,19 & 0,20 & 0,17 & 0,25 & 0,13 & 0,18 & 0,11 & 0,18 & 0,11 & 0,25 & 22 \\
\hline 14 & Klbris & 0,15 & 0,16 & 0,23 & 0,20 & 0,26 & 0,13 & 0,17 & 0,09 & 0,20 & 0,12 & 0,26 & 25 \\
\hline 15 & Letonya & 0,20 & 0,24 & 0,14 & 0,08 & 0,29 & 0,27 & 0,20 & 0,20 & 0,15 & 0,18 & 0,29 & 34 \\
\hline 16 & Litvanya & 0,15 & 0,26 & 0,11 & 0,17 & 0,19 & 0,15 & 0,10 & 0,20 & 0,23 & 0,20 & 0,26 & 27 \\
\hline 17 & Luxemburg & 0,11 & 0,03 & 0,08 & 0,03 & 0,23 & 0,07 & 0,17 & 0,02 & 0,07 & 0,09 & 0,23 & 20 \\
\hline 18 & Macaristan & 0,23 & 0,23 & 0,16 & 0,19 & 0,22 & 0,26 & 0,15 & 0,22 & 0,10 & 0,07 & 0,26 & 28 \\
\hline 19 & Malta & 0,21 & 0,11 & 0,11 & 0,27 & 0,23 & 0,17 & 0,25 & - & 0,07 & 0,16 & 0,27 & 31 \\
\hline 20 & Hollanda & 0,08 & 0,05 & 0,06 & 0,02 & 0,22 & 0,09 & 0,02 & 0,07 & 0,11 & 0,08 & 0,22 & 16 \\
\hline 21 & Avusturya & 0,13 & 0,12 & 0,17 & 0,10 & 0,13 & 0,07 & 0,03 & 0,04 & 0,19 & 0,10 & 0,19 & 9 \\
\hline 22 & Polonya & 0,21 & 0,27 & 0,15 & 0,22 & 0,21 & 0,29 & 0,21 & 0,16 & 0,15 & 0,16 & 0,29 & 33 \\
\hline 23 & Portekiz & 0,17 & 0,16 & 0,10 & 0,15 & 0,22 & 0,11 & 0,18 & 0,16 & 0,17 & 0,18 & 0,22 & 18 \\
\hline 24 & Romanya & 0,27 & 0,27 & 0,19 & 0,24 & 0,32 & 0,29 & 0,21 & 0,25 & 0,24 & 0,14 & 0,32 & 37 \\
\hline 25 & Slovenya & 0,08 & 0,18 & 0,16 & 0,22 & 0,15 & 0,14 & 0,08 & 0,15 & 0,18 & 0,11 & 0,22 & 17 \\
\hline 26 & Slovakya & 0,18 & 0,24 & 0,21 & 0,23 & 0,25 & 0,24 & 0,16 & 0,23 & 0,11 & 0,06 & 0,25 & 23 \\
\hline 27 & Finlandiya & 0,05 & 0,12 & 0,02 & 0,06 & 0,13 & 0,07 & 0,05 & 0,03 & 0,16 & 0,11 & 0,16 & 3 \\
\hline 28 & Isveç & 0,03 & 0,06 & 0,01 & 0,06 & 0,09 & 0,09 & 0,05 & 0,02 & 0,09 & 0,10 & 0,10 & 1 \\
\hline 29 & Birleşik Krallık & 0,07 & 0,07 & 0,16 & 0,07 & 0,18 & 0,14 & 0,05 & 0,15 & 0,07 & 0,01 & 0,18 & 6 \\
\hline 30 & Izlanda & 0,11 & 0,08 & - & 0,06 & 0,15 & 0,07 & 0,01 & 0,19 & 0,06 & 0,20 & 0,20 & 10 \\
\hline 31 & Israil & 0,17 & 0,15 & 0,17 & 0,20 & - & 0,16 & 0,04 & 0,11 & - & 0,08 & 0,20 & 11 \\
\hline 32 & Makedonya & 0,24 & 0,22 & 0,23 & 0,22 & 0,24 & 0,19 & 0,20 & 0,26 & 0,29 & 0,18 & 0,29 & 36 \\
\hline 33 & Norveç & 0,08 & 0,11 & 0,08 & 0,01 & 0,15 & 0,07 & 0,04 & 0,21 & 0,15 & 0,17 & 0,21 & 14 \\
\hline 34 & Sirbistan & 0,20 & 0,27 & 0,27 & 0,21 & 0,16 & 0,16 & 0,11 & 0,24 & 0,15 & 0,15 & 0,27 & 29 \\
\hline 35 & Isviçre & - & - & 0,08 & 0,05 & 0,01 & - & 0,04 & 0,01 & 0,11 & 0,04 & 0,11 & 2 \\
\hline 36 & Ukrayna & 0,13 & 0,28 & 0,29 & 0,25 & 0,28 & 0,26 & 0,25 & 0,26 & 0,17 & 0,21 & 0,29 & 35 \\
\hline 37 & Türkiye & 0,25 & 0,26 & 0,17 & 0,18 & 0,14 & 0,14 & 0,16 & 0,27 & 0,28 & 0,16 & 0,28 & 32 \\
\hline
\end{tabular}

\section{Kaynakça}

Adıgüzel, B. (2012). Inovasyon ve inovasyon yönetimi: Steve Jobs örneği. Yayımlanmamış yüksek lisans tezi, Gazi Üniversitesi Sosyal Bilimler Enstitüsü, Ankara.

Atik, H. ve Özbek, H. (2012). İnovasyon göstergeleri bakımından Türkiye’nin Avrupa Birliği ülkeleri arasındaki yeri: İstatiksel bir analiz. Erciyes Üniversitesi İktisadi ve İdari Bilimler Fakültesi Dergisi, 42, 193-210.

Autant-Bernard, C., Chalaye, S., Manca, F., Moreno, R.ve Surinach, J. (2010). Measuring the adoption of innovation a typology of EU countries based on the innovation survey. Innovation: the European Journal of Social Science Research, 23, 199-222.

Eleren, A. ve Karagül, M. (2008). "1986-2006 Türkiye ekonomisi performans değerlendirmesi” Celal Bayar Üniversitesi Ikktisadi ve İdari Bilimler Fakültesi Yönetim ve Ekonomi Dergisi, 15 (1), 110-111.

Ettlie, J. E., Bridges, W. P. ve O'Keefe, R. D. (1984). Organization strategy and structural differences for radical vs. incremental innovation. Management Science, 30, 682-695. 
Fernández-Ribas, A. (2010). International patent strategies of small and large firms: An empirical study of nanotechnology. Review of Policy Research, 27, 55.

Işık, C. ve Keskin, G. (2013). Bilgi ekonomilerinde rekabet üstünlüğü oluşturulması açısından inovasyonun önemi. Atatürk Üniversitesi İktisadi ve İdari Bilimler Dergisi, 27(1), 41-57.

İnel, M. N. ve Türker, M. V. (2016). Ulusal inovasyon performansının ölçümü için çok nitelikli karar verme teknikleri ile bir model denemesi. Marmara Üniversitesi İktisadi ve İdari Bilimler Dergisi , 38(2), 147-166.

Jungmittag, A. (2004). Innovations, technological specialization and economic growth in the EU. International Economics and Economic Policy, 1 (2-3), 247-273.

Karaata, S. (2012). İnovasyon ölçümünde yeni arayışlar, İstanbul: TÜSİAD- Sabanc1 Üniversitesi Rekabet Formu.

Kaynak, S., Altuntaş, S. ve Dereli, T. (2017). Comparing the innovation performance of EU candidate countries: An entropy-based TOPSIS approach. Economic Research, 30(1), 31-54.

Lööf, H., Heshmati, A., ve Naas, R. A.O. (t.y.). Innovation and performance in manufacturing industries: A comparison of the Nordic countries. SSE/EFI Working Paper Series in Economics and Finance, (457), 119-120.

Mercan, B., Gömleksiz, M. (2013). Bölgesel kalkınmada inovasyon sistemleri yaklaşımı: Kop bölgesi üzerine bir inceleme. UNIKOP 1. Kop Bölgesel Kalkınта Sempozyumu. 4-9. Http://unikop.org/makale/KS13-7-08.pdf. Erişim tarihi: 23.04.2018

Nafgizer, E. W. (2006). Economic development (4th ed.). Cambridge; Cambridge University.

Oslo, M. (2006). The measurement of scientific and technological activities. Proposed Guidelines for Collecting and Interpreting Technological Innovation Data. European Commission and Eurostat-Manual de Oslo-Diretrizes Para Coleta E İnterpretação De Dados Sobre İnovação. Traduzido pela FINEP,.

Oprean, C., ve Tănăsescu, C. (2007). The convergence degree of innovation potential of Romanian economy, by comparison with the developed economies of the EU Member States. The Romanian Economic Journal, 25, 285-304.

Örücü, E., Kılıç, R. ve Savaş, A. (2011). KOBI'lerde inovasyon stratejileri ve inovasyon yapmayı etkileyen faktörler: bir uygulama. Doğuş Üniversitesi Dergisi, 12 (1), 58-73.

Özdemir, M. (2015). TOPSIS. Çok Kriterli Karar Verme Yöntemleri. Bursa: Dora Basım-Yayım.

Paas, T., ve Poltimäe, H. (2010). A comparative analysis of national innovation performance: The Baltic states in the EU context. University of Tartu Faculty of Economics and Business Administration. http://ssrn.com/abstract=1722717 doi:10.2139/ssrn.1722717 Erişim Tarihi: 30.04 .2018

Pan, T. W., Hung, S. W., ve Lu, W. M. (2010). Dea performance measurement of the national innovation system in Asia and Europe. Asia-Pacific Journal of Operational Research, 27, 369-392.

Suurna, M., ve Kattel, R. (2010). Europeanization of innovation policy in central and eastern Europe. Science and Public Policy, 37, 646-664.

Şahinli, M. A., ve Kılınç, E. (2013). İnovasyon ve inovasyon göstergeleri: ab ülkeleri ve türkiye karşılaştırması. Sosyal Ekonomik Araştırmalar Dergisi, 13(25), 329-356.

Tokumasu, S., ve Watanabe, C. (2008). Institutional structure leading to the similarity and disparity in innovation inducement in EU 15 countries-finnish conspicuous achievement triggered by Nokia's IT driven global business. Journal of Services Research, 8, $1-$ 38.

Uğur, L. O. (2017). MOORA optimizasyon yaklaşımı ile inşaat proje müdürü seçimi: Çok kriterli bir karar verme uygulaması. Politeknik Dergisi, 20(3), 717-723.

Urfalıoğlu, F. ve Genç, T. (2013). Çok kriterli karar verme teknikleri ile Türkiye'nin ekonomik performansının Avrupa birliği üye ülkeleri ile karşılaştırılması. Marmara Üniversitesi İktisadi İdari Bilimler Fakültesi Dergisi, 35 (2) , 329-360.

Uzgören, E., Elevli, B. (2011). Çok değişkenli istatistiksel yöntemlerle Türkiye ve AB ülkelerinin Ar-Ge ve inovasyon göstergeleri yönünden sinıflandırılması. Dumlupınar Üniversitesi İktisadi İdari Bilimler Fakültesi Akademik Platform Dergisi, 34-67.

Ünlükaplan, İ. (2009). The spesification of the relationship between economic development, competitiveness and innovation in European union using canonical correlation analysis. Maliye Journal, 157, 235-250.

Yıldırım, B. F. ve Önder E. (2015). Çok kriterli karar verme yöntemleri. Bursa. Dora Yayınları, 245-250. 